2. Дендрофлора України. Дикорослі та культивовані дерева й кущі. Голонасінні : довідник / М. А. Кохно, В. І. Гордієнко, Г. С. Захаренко та ін. ; за ред. М. А. Кохна, С. І. Кузнецова ; НАН України, Нац. бот. сад ім. М. М. Гришка. К. : Вища шк., 2001. - 207 с.

3. Дендрофлора України. Дикорослі та культивовані дерева й кущі. Покритонасінні. - Ч. І. : довідник / М. А. Кохно, Л. І. Пархоменко, А. У. Зарубенко та ін.; за ред. М. А. Кохна. - К. : Фітосоціоцентр, 2002. - 448 с.

4. Дендрофлора України. Дикорослі та культивовані дерева й кущі. Покритонасінні. - Ч II : довідник / [М. А. Кохно, Н. М. Трофименко, Л. І. Пархоменко та ін. ; за ред. М. А. Кохна та Н. М. Трохименко]. - К. : Фітосоціоцентр, 2005. - $716 \mathrm{c}$.

5. Калініченко О. А. Декоративна дендрологія : навч. посіб. / О. А. Калініченко. - К. : Вища шк., 2003. - 200 с.

6. Колесников А. И. Декоративная дендрология / А. И. Колесников. - М. : Лесн. пром., 1974. - 704 с.

7. Мисник Г. Е. Календарь цветения деревьев и кустарников / Г. Е. Мисник. - М. : Изд-во Мин. коммунального хоз. РСФСР, 1956 - 174 c.

8. Мисник Г. Е. До оцінки декоративності дерев та чагарників у фазах їх цвітіння та плодоношення / Г. Е. Мисник // Біологія і культура деревних та чагарникових рослин. - К. : Наук. думка, 1964. - С. 100-101.

9. Савоськіна А. М. Біоморфологічна та екологічна структура екзотичної дендросозофлори штучних заповідних парків Українського Полісся / А. М. Савоськіна // Науковий вісник Східноєвропейського національного університету імені Лесі Українки : наук. журн. - Луцьк : Біологічні науки, 2016. - № 7 (302). - С. $59-65$.

10. Савоськіна А. М. Особливості складу дендросозофітів парків-пам'яток садово-паркового мистецтва Українського Полісся / А. М. Савоськіна // Біоресурси лісових та урбанізованих екосистем: відтворення, збереження і раціональне використання : тези доп. уч. Міжнар. наук.-прак. конф. (23-24 квіт. 2015 р.). - К. : «ЦП «Компринт», 2015. - С. 166-167.

Савоскина Анна. Оценка декоративности дендросозоэкзотов искусственных заповедных парков Украинского Полесья. В статье оценена степень декоративности дендросозоэкзотов ех situ искусственных заповедных парков Украинского Полесья. Для этого использовали новую комплексную методику оценки декоративности, которая разработана специально для дендросозоэкзотов на основе оценки их декоративных признаков. В результате анализа выявлено, что из 105 видов дендросозоэкзотов 69 (65,7 \%) видов имеют высокую декоративность и очень высокую - три вида. Посредственной декоративностью отличаются 23 (21,9 \%) вида, низкой - 10 (10,0 \%) видов.

Ключевые слова: Украинское Полесье, декоративность древесных растений, дендросозоэкзоты, искусственные заповедные парки.

Savoskina Anna. Evaluation of Decorativeness of Dendrosozoekzots of the Ukrainian Polissya. In this article assessed the degree of decorativeness artificial dendrosozoekzots ex situ artificial protected parks in Ukrainian Polissya. For this purpose use a new comprehensive methodology for assessing decorativeness that is designed specifically for dendrosozoekzots based on their assessment of decorative signs. The analysis found that of the 105 species dendrosozoekzots $69(65,7 \%)$ species are highly decorativeness and very high decorativeness - the three species. Middling decorativeness are $23(21,9 \%)$ species, low decorativeness - $10(10,0 \%)$ species.

Key words: Ukrainian Polissya, decorativeness arboreal plants, dendrosozoekzots, artificial protected parks.

Стаття надійшла до редколегї 19.09.2016 р.

УДК:58.009

Дмитро Ганаба

\title{
Озеленення міста Хмельницького в другій половині ХХ ст.
}

У статті розглянуто особливості озеленення міської інфраструктури Хмельницького в другій половині ХХ ст. На основі документів відділу міського комунального господарства проаналізовано стан озеленення міста. Указано на масштабність комплексу заходів з озеленення, що здійснювалися на основі партійних і державних програм. Позитивний фактор у процесі озеленення - залучення громадськості у висадці та догляді за молодими насадженнями. Характерним недоліком у процесі озеленення, що набуває поглиблення й дотепер, є безсистемність у доборі асортименту рослин, незначна різноманітність їх видового складу, відсутність наукового підходу в проектах озеленення міста тощо. У процесі озеленення практично не враховували кліматичних характеристик міської території, санітарно-гігієнічних умов й екологічних особливостей урбанізованого середовища тощо.

Ключові слова: деревні насадження, озеленення, урбоекологічна система, комплекс заходів, методи, рослини.

(ㄷ Ганаба Д., 2016 
Постановка наукової проблеми та її значення. Озеленення міст - важлива проблема сучасного містобудування. Ї̈̈ актуальність і значимість зумовлена, по-перше, необхідністю збереження й розвитку оптимального життєвого середовища для людини в умовах інтенсивного розвитку інфраструктури міста; по-друге, потребою створення стійкої урбоекологічної системи в умовах погіршення екологічної ситуації, докорінної антропогенної трансформації рослинного й тваринного світу та, загалом, зміни антропологічних ландшафтів людського буття; по-трете, потребою використання зелених насаджень як важливого композиційного елемента в плануванні, забудові й благоустрої населених пунктів; по-четверте, необхідністю поліпшення санітарно-гігієнічних умов проживання людей, створенні природного пейзажного середовища та джерела комфортного естетичного відпочинку в місті тощо.

Актуальність і значимість проблеми озеленення міст набуває особливої гостроти в умовах сучасних економічних реалій. У містах дедалі частіше квадратні метри міського простору використовують із комерційною метою, здійснюючи масштабну забудову задля отримання прибутку. Така ситуація засвідчує скорочення «зелених» метрів й указує на недотримання санітарних норм щодо озеленення. Це спостерігається в більшості сучасних українських міст, зокрема й у Хмельницькому. За даними екологічної інспекції, Хмельницький за рівнем озеленення займає лише 21 місце в Україні серед обласних центрів. При нормі від 12 кв. м до 24 кв м. на людину в цьому населеному пункті цей показник становить близько 5 кв. м і має тенденцію до щорічного зменшення [28].

Водночас для створення комфортних умов життя в населених пунктах, на думку науковців, на кожного мешканця згідно із санітарними нормами повинно припадати не менше 350 кв. м зелених насаджень, у тому числі 50 кв. м безпосередньо в населеному пункті [27]. Зрозуміло, що окреслена проблема є складною й багатогранною, а тому потребує комплексного розв'язання. Ідеться про необхідність пошуку оптимальних методів та способів озеленення сучасних міст, визначення умов розвитку рослин в умовах посилених техногенних навантажень, підбір асортименту й розробку агротехніки вирощування зелених насаджень тощо. Суттєву роль у розв'язанні цих проблем може відіграти досвід минулих років. Розгляд особливостей озеленення міської інфраструктури минулих років дасть змогу показати не лише недоліки, а й виокремити позитивні сторони, які можуть бути використані в перспективі.

Мета статті - розгляд особливостей озеленення міської інфраструктури міста Хмельницького в другій половині XX ст. Окреслена мета реалізується за допомогою низки завдань: 1) проаналізувати стан озеленення міста у XX ст.; 2) визначити основні напрями роботи з озеленення й благоустрою міста в минулі роки; 3) виокремити позитивні сторони роботи з озеленення міста, що можуть бути використанні в перспективі.

Анвліз досліджень цієї проблеми. Теоретичні підходи до благоустрою й озеленення сучасних міст відображено в роботах Д. Орлова, Ю. Бочарова, М. Болотова, А. Вороніна, О. Кудрявцева та ін. Методологічні засади дослідження проблем озеленення проаналізовано Е. Говардом й Л. Корбюзьє, які у своїх працях презентували концепцію місто-сад. Концепція лінійного міста (планування міста за лінійною структурою - складається з трьох смуг - промислової, зеленої й житлової) представлена в дослідженнях Н. Ладовського, В. Лаврова, А. Пастернака та ін. Питання управлінням озелененням i благоустроєм міста висвітлено в наукових розвідках В. Тоболіна, В. Зотова, Ю. Хотунцева, Г. Ількуна, Ф. Левона. Розкриття проблем озеленення сучасних українських міст презентовано в дослідженнях Ю. Богданової, В. Кучерявого, М. Курницької, Н. Ковальчук, О. Піхало та інших.

Виклад основного матеріалу й обгрунтування отриманих результатів дослідження. Хмельницький - адміністративний, економічний, культурний центр Хмельницької області. Він розміщений у межах Подільської височини на берегах річки Південний Буг, у місці впадання в неї річки Плоскої. Хмельницький належить до категорії великих міст України. На сьогодні його територія займає площу близько 93,05 кв. км. Чисельність населення станом на 01 травня 2016 р. - 269308 мешканців [19]. Хмельницький має майже 600-річну історію, яка бере початок від поселення Плоскирів, або Плоскирівці. Протягом тривалого часу місто залишалося невеликим населеним пунктом і лише після приєднання наприкінці XVIII ст. Поділля до Російської імперії отримує статус повітового міста. Як промисловий та економічний центр населений пункт починає розвиватися на початку XX ст. Місто поступово розбудовується й стає найбільшим за кількістю населення, промисловим потенціалом і військовостратегічним значенням у регіоні, а згодом, у березні, - обласним центром Кам'янець-Подільської 
області [18]. Забудова міста передбачала розбиття нових парків і скверів, висадження чималої кількості рослин на вулицях та прибудинкових територіях міста тощо. Згідно з відомостями про благоустрій міста в 1936-1938 рр. загальна площа зелених насаджень складала 36,5 га (на одну людину припадає - 9,3 кв. м) [7].

Мирне життя та розбудову міста перервано роками воєнного лихоліття. Після закінчення Другої світової війни розпочинається відбудова фактично нового міста, яке - 16 січня 1954 р. перейменовано в Хмельницький із відповідним перейменуванням області. Будується низка підприємств індустріально-будівельної, харчової, легкої промисловості, значно збільшується площа міста, особливо після приєднання приміських сіл Заріччя та Гречани [19]. У місті створено нові мікрорайони, планується нова житлова забудова, закладають нові сквери, парки, вулиці. Зокрема, у 1948 р. закладено один із найбільших парків міста Хмельницького - парк імені 50-річчя Жовтня (нині - імені M. Чекмана), зазнають реконструкції сквер імені Т. Шевченка й парк імені І. Франка. Виконуються архітектурно-планувальні роботи з благоустрою міста, у яких важливу роль відведено озелененню. Аналіз документів відділу комунального господарства виконавчого комітету Хмельницької міської ради депутатів, а саме: річних планів фінансування об'єктів благоустрою, планів роботи міськкомунгоспу, планів комплексного благоустрою міста, довідок про виконаний обсяг робіт із благоустрою міста тощо - засвідчив масштабність комплексу заходів з озеленення й ландшафтної реконструкції зелених насаджень міста в другій половині XX ст.

Серед заходів із благоустрою міста, проведених Проскурівським (нині - місто Хмельнииький) комунгоспом, передбачено висадження чималої кількості дерев у парках, скверах і вулицях. Так, у планах розвитку житлово-комунального господарства на 1950-1958 рр. планувалося висадити 8350 деревних рослин [8]. Окреслені завдання реалізовувалися в щорічних планах благоустрою міськкомунгоспу. Аналіз документів засвідчив значне перевиконання запланованих показників. Зокрема, лише в річному звіті з благоустрою міста за 1950 р. зазначено про висадження 9400 дерев [36]. У 1951 р. також простежено понадпланове збільшення кількості висаджених зелених насаджень у місті. Зокрема, у плані заходів із благоустрою міста на цей рік передбачено висадження 1000 деревних насаджень. У довідці про результати роботи житлово-комунального підприємства міста за 1951 р. зазначено, що висаджено дерев - 5140 штук (що в п’ять разів перевищило заплановані показники), а також кущів - 2300 штук, квітів - 195494 штук [12]. У 1952 р. серед заходів Проскурівського комунгоспу з благоустрою міста планувалося висадити дерев у кількості 20 тис. (силами громадськості 15 тис.) у парках, скверах і вулицях, зокрема Лагерній, Глухій, Суворова, Шестакова, Старокостантинівського шосе тощо [5].

Наступна особливість - широкомасштабне озеленення низки вулиць міста. У межах проведеної реконструкції й благоустрою передбачено не лише ремонт доріг і тротуарів, установлення вуличних ліхтарів, а й розбиття клумб та висадка дерев і кущів, збереження й омолодження наявних рослин. Як приклад, архітектурно-планувальні завдання з благоустрою міста в 1958 р. передбачали озеленення вулиць Короленка, Котовського (нині - вул. Проскурівського підпілля), Франка, Шевченка, Пілотської, Дзержинського (нині - вул. Свободи), провулків Червоноармійського (нині - Свропейський), Кірова (нині - вул. Володимирськоі) [13]. У 1959 р., згідно з архітектурно-планувальних завдань, озеленено вулиці Пушкіна, Короленка, Суворова, Танкістів, Котовського (нині - вул. Проскурівського підпілля), Старобульварної (нині - вул. Гагаріна), Фабричної, Жданова (нині - вул. Шевченка) [14]. Зазначені заходи продовжились і в наступні роки. У 60-70-х pp. XX ст. проведено озеленення як вулиць центральної частини міста, так і щойно закладених вулиць у мікрорайонах новобудов. Зокрема, у річному плані з благоустрою міста на 1960 р. серед заходів Хмельницького комунгоспу зазначено про висадження 8 тис. дерев віком 10 років на вулицях Танкістів, Карла Лібнехта (нині вул. Подільська), Котовського (нині - вул. Проскурівського Підпілля), Водопровідній, Жданова (нині вул. Шевченка), Тельмана (нині - вул. Вайсера), бульвару Дзержинського(нині - вул. Свободи). На узбережжі річки Південний Буг висаджено 22 тис. деревних рослин [15]. У цьому ж році проведено благоустрій та озеленення вулиць Кірова (нині - вул. Володимирська), Шевченка, Горького, Толстого, провулка Кожедуба [9]. У плані комплексного благоустрою міста за 1974 р. передбачено ландшафтну реконструкцію й озеленення вул. Центральної (нині - вул. Проскурівська) [3].

Потрібно зазначити, що благоустрій та озеленення вулиць міст здійснювалися відповідно до державних і партійних рішень та програм. У них зазначено про потребу створення в обласних 
центрах великих промислових і курортних містах зелених зон, парків та вулиць як еталонів узірцевого комплексного благоустрою. У Хмельницькому таким еталонним зразком стала вулиця Куйбишева (нині - вул. Зарічанська) (від вул. Дзержинського(нині - вул. Свободи) до Староконстантинівського шосе), масштабний благоустрій та озеленення якої проведено в 1977 р. [4].

Зрозуміло, що роботи з озеленення вимагали використання чималих коштів. Органами влади міського й обласного рівнів щороку виділялися тисячі карбованців. У 1950-1955 рр. на проблеми озеленення міста Хмельницького використано 67 тис. карбованців. У наступні роки фінансові вкладення коштів лише зростали. У 70-х рр. вони складали близько 20 тис. карбованців щорічно. Попри виділення значної суми коштів, характерним недоліком озеленення обласного центру другої половини XX ст. була незначна різноманітність їх видового складу, безсистемність у доборі асортименту рослин, відсутність наукового підходу в проектах озеленення міста тощо. У процесі озеленення практично не враховували кліматичні характеристики міської території, санітарногігієнічні умови й екологічні особливості урбанізованого середовища тощо. Зазвичай, висаджували ті види рослин, які були в розсадниках, так би мовити, «під руками». Як приклад, у 1950 р. у Хмельницькому висаджено 1000 саджанців кущів жовтої акації (Caraganaarborescens), 1500 штук 2-річної тополі пірамідальної (Populuspyramidalis Roz) 4500 саджанців одно- та дворічного клена американського (Acernegundo) й 1300 рослин трьох- і чотирьохрічного клена американського (Acernegundo) 1000 штук посадкового матеріалу дичок яблуні (Malussylvestris) та 100 штук яблуні домашньої (Malussylvestris) на загальну суму 10600 руб. [10]. За даними звітності міської контори 3 благоустрою 1957 р., у місті висаджено 420 саджанців гіркокаштану кінського (Aesculushippocastanum), 2500 рослин берези повислої (Betula pendula), 1275 живців тополі пірамідальної (Populus pyramidalis Roz), 530 штук посіву клена американського (Acernegundo), 4200 штук саджанців жовтої акації (Caraganaarborescens), 1300 - рослин клена гостролистого (Acerplatanoides), 69 саджанців щепи яблуні (Malussylvestris) і 48 - щепи сливи (Prúnusdoméstica). В озелененні також використано рідкісні види рослин, а саме: три саджанці лавра вишні (Prúnus laurocerásus), два юки (Yúcca), 18 циперуса (Cyperus), 30 - олеандру (Nérium) й одну тую (Thúja) [11]. Практично рідкісні рослини висаджувались у парках та на вулицях міста лише поодинокими екземплярами, що зумовлювало не лише не врахування пейзажного середовища, а й негативно впливало на санітарно-гігієнічні умови й комфортне проживання мешканців.

Цікаво, що ця проблема знайшла відображення не лише в наукових розвідках дослідників, а й у міркуваннях пересічних громадян. Озеленення міста Хмельницького активно обговорювалося на шпальтах міської й обласної преси. Зокрема, дописувачі газети «Радянське Поділля» стверджували, що парки та сквери створюються, зазвичай, без науково обгрунтованих проектів, до того ж матеріалом, узятим із лісу. Вони наголошують, що «багато з цих насаджень уже перетворились у звичні зарослі й потребують реконструкції. Не все в нас гаразд 3 озелененням територій новобудов. Комунальне господарство, із якими будівельники укладають угоду на посадку дерев, також роблять це без будь-яких проектів, засаджують матеріалом, який у цей час під руками...» [20]. Відсутність належного декоративного рослинного матеріалу зумовлює недооцінку значення рослин як композиційного елемента, що доповнює, оживляє й прикрашає архітектуру будівель, міських кварталів і вулиць. Ідеться про те, що висадка «випадкової» рослинності здатна зіпсувати архітектурнохудожній виклад міста. Дописувачі газети «Радянське Поділля» радять міськомунгоспу, конторі 3 благоустрою міста й управлінню архітектури в проектах забудови вулиць та їх озеленення звернути увагу на підбір цінних порід дерев і кущів, урахування правильного розміщення й догляд за цими насадженнями, належну оцінку їх значення як композиційного елемента в архітектурі міста тощо [24]. Потрібно зазначити, що ця проблема не лише залишається актуальною, а й отримала тенденцію до поглиблення за відсутності науково обгрунтованого підходу до їі розв’ язання.

Досвід минулих років засвідчив, що, окрім державних установ, також мешканці міста сприяли озелененню населеного пункту, проводили низку заходів зі збереження рослинності. Зокрема, на сторінках преси небайдужі мешканці звертають увагу на необережне, негосподарське ставлення до зелених насаджень. Так, до редакції газети «Радянське Поділля» надходить чимало листів від мешканців міста, зокрема Південно-Західного житлового масиву. Вони вказують, що «на цій території висаджено захисні зелені насадження 3 дубків й акацій у вигляді алей відпочинку. Проте будівельники під час будівельних робіт часто-густо ламають рослини бульдозерами, звалюють між дере- 
вами залізобетонні конструкції, будують тимчасові курені тощо. Після них залишаються покалічені дерева, захаращені місця» [22]. Потрібно зазначити, що в 50-80-х pp. ХX ст. серед мешканців Хмельницького набула поширення практика догляду містян за зеленими насадженнями. Так, ЖЕК-4 розподілила обов'язки 3 догляду за вуличними саджанцями між жителями сусідніх будинків. Зокрема, за мешканцями будинку №78/3 на проспекті Миру закріплено понад 100 ялинок. На кожній із них зазначено номер квартири. Майже всі саджанці прижилися. Всохли лише дерева, за якими доглядали родини С. Коваля й А. Дузяка, за що були піддані громадському осуду на шпальтах обласної преси [22]. Практика використання зусиль громадськості в збереженні рослин і збільшення їх кількості й асортименту в парках, скверах та вулицях міста має бути врахована в перспективних планах з озеленення. Вона повинна стати дієвою $з$ огляду на ту обставину, що в Хмельницькому в останні роки висаджується щороку понад 2000 дерев, із яких не приживаються близько 20 \% [27].

Наступна особливість озеленення міста в минулі роки - зв'язок із масштабними державними святами та ювілейними датами. Із-поміж низки таких подій потрібно відзначити підготовку й святкування хмельничанами 100-річчя 3 дня народження В. І. Леніна. Міський виконавчий комітет на виконання Постанови ЦК КП України «Про ініціативу трудящих Києва, Жданова і Кам’янцяПодільського в організації соціалістичного змагання міст республіки по благоустрою на честь 100річчя 3 дня народження В. І. Леніна» затвердив низку заходів з озеленення міста. Передбачено «озеленити» території промислових підприємств, навчальний закладів, «збагатити й поліпшити декоративно-художнє обличчя вулиць міст, площ, мікрорайонів старої й нової забудови» [21]. Працівники житлово-комунального господарства брали зобов' язання посадити 7350 дерев, 1500 тис. троянд і кущів, понад 2 тис. погонних метрів живої огорожі, засіяти зелені газони на площі 5 га. На озеленення міста міськрада виділила понад 90 тис. крб [21]. Реалізація заходів з озеленення міста на честь 100-річчя з дня народження В. І. Леніна розпочалася ще в 1968 р. Висаджено 8797 деревних рослин при плані 6334 шт. [6]. У наступному році робота з озеленення продовжилася. У першому півріччі 1969 р. проведено озеленення вулиць Леніна, 25 Жовтня, Кірова (нині - вул. Володимирівська), Рози Люксембург. Завершені роботи зі створення нового скверу на вул. Карла Лібкнехта (нині - вул. Подільська) [6]. У другій половині цього року завершено впорядкування зеленої зони на вулиці Куйбишева (нині - вул. Зарічанська) та виконані роботи з реконструкції зелених насаджень вулиці Леніна. У річному плані фінансування об'єктів благоустрою міста на 1970 р. зазначено використання значної суми коштів на озеленення обласного центру. Зокрема, на вулицях міста висаджено 3125 дерев. Озеленення деревами, що досягли віку 12-15 років, проводили на вулицях Леніна (нині - вул. Проскурівська) (22 шт.), М. Трембовецької (170 шт.), 25 Жовтня (нині - вул. Проскурівська) (6 шт.), Львівському шосе (22 шт.), провулку Нєкрасова (40 шт.), на Військовому кладовищі (22 шт.) - усього 282 дерева. Висадку дерев віком 8-10 років проводили на вулицях Тернопільській (50 шт.), Індустріальній (нині - вул. Чорновола) (115 шт.), на проспекті Миру (200 шт.), бульварі Дзержинського (нині - вул. Свободи) (30 шт.), братській могилі в районі автодрому (30 шт.), на Новому кладовищі (400 шт.) - усього 3125 дерев [1]. Потрібно зазначити, що практика пов' язувати закладення нових скверів, парків та алей із державними святами чи громадськими акціями зберігається й сьогодні. Зокрема, у 2006 р. в акції з нигоди відзначення Дня довкілля в мікрорайоні Дубово висаджено саджанці дуба червоного й берези звичайної [16]. Учасники акції «Дерева Миру» в цьому ж році висадили в мікрорайоні Озерна близько 80 саджанців лип, дубків, горобини звичайної [16; 17].

У 80-90-х рр. озеленення міста продовжувалося. Необхідність розширення площ зелених насаджень було пов'язане, з одного боку, зі збільшенням розмірів міської агломерації (у середині 80-х років до міста приєднано приміське село Ружична, закладено нові вулиці, збільшено протяжність уже існуючих тощо), із другого - погіршенням екологічної ситуації на тлі збільшення об'єктів промисловості й інтенсивності руху міського транспорту. Науковці, аналізуючи екологічний стан Хмельницького в середині 80-х років XX ст., указують, що «щодоби по головних артеріях міста вулицях Карла Маркса, Фрунзе, Купріна (нині - вул. Володимирівська), Куйбишева (нині - вул. Зарічанська), Староконстанівського шосе й проспекту Миру) - проходить близько 18 тис. автомашин...» [26, с. 3]. Вони радять збільшити площу зелених насаджень у розрахунку на одного мешканця за рахунок вертикального озеленення на будинках [26, с. 3]. У 80-х роках XX ст. виконком міської ради намітив комплексний план благоустрою парків, вулиць і скверів. На його реалізацію витрачено понад 900 тис. крб. Нові парки закладено в Південно-Західному мікрорайоні (Львівське 
шосе - вулиця Молодіжна) та Південному (вулиця Куйбишева (нині - вул. Зарічанська)), упорядковано дендропарк і сквер імені І. Франка. У північній частині міста закладено парк площею 100 га [26]. Мешканці мікрорайону Гречани розбили на вулиці Ворошилова парк культури та відпочину й посадили понад 17 тис. дерев і кущів [26].

Висновки та перспективи подальшого дослідження. Одним зі способів розв'язання складного спектра екологічних проблем сучасного міста $€$ його озеленення. У пошуку ефективних методів i способів озеленення, створення багатого асортименту рослин і розробки агротехніки їх вирощування важливе надбання минулих років. Проаналізований досвід озеленення міста Хмельницького в другій половині XX ст. засвідчив широкомасштабний комплекс заходів з озеленення й ландшафтної реконструкції зелених насаджень. Сьогодні закладалися нові парки й сквери, висаджували чималу кількість дерев і кущів на вулицях населеного пункту, проводили роботи зі збереження й омолодження наявних рослин тощо. Благоустрій та озеленення здійснювали відповідно до державних і партійних програм. На заходи щороку виділялися великі кошти. В обласних містах та великих промислових центрах створювали зелені зони як еталони взірцевого благоустрою, у Хмельницькому - це вулиця Куйбишева (нині - вул. Зарічанська). Позитивним фактором у процесі озеленення є залучення громадськості до висадки чималої кількості дерев і кущів та догляду за молодими насадженнями. Особливістю озеленення Хмельницького, що збереглася й сьогодні, $є$ зв'язок із державними святами й ювілеями. Негативний фактор у процесі озеленення, що набуває поглиблення й дотепер, є безсистемність у доборі асортименту рослин, незначна різноманітність їх видового складу, відсутність наукового підходу в проектах озеленення міста тощо. У процесі озеленення практично не враховували кліматичні характеристики міської території, санітарно-гігієнічні умови й екологічні особливості урбанізованого середовища тощо.

Оскільки, теорія й практика озеленення населених пунктів повинні грунтуватися на науково обгрунтованих принципах і підходах у перспективі подальших досліджень потрібно розглянути стан екотопів міських насаджень міста Хмельницького та оцінку їх впливу на життєвість рослин.

\section{Джерела та література}

1. ДАХО, ф.1178, оп. 4, спр. 203 Годовые планы финансирования внелимитных капиталовложений, капремонта и текущих мероприятий объектов благоустройства 1970 год, арк. 27.

2. ДАХО, ф.1178, оп. 4, спр. 244 Годовой план финансирования внелимитных капиталовложений, капремонта и текущих мероприятий объектов благоустройства города на 1973 год, арк. 14.

3. ДАХО, ф.1178, оп. 4, спр. 257 Годовой план финансирования объектов благоустройства по внелимитным капиталовложениям капремонта и текущим мероприятиям за 1974 год, арк. 57.

4. ДАХО, ф.1178, оп. 4, спр. 299 Планы по комплексному благоустройству города на 1977 год, арк. 8.

5. ДАХО, ф.1178, оп. 4, спр. 56 Справки о выполненных работах по благоустройству города за 1952 год, арк. 9.

6. ДАХО, ф.1178, оп. 4, спр. 196 Мероприятия по благоустройству города в честь 100-летия со дня рождения В. И. Ленина на 1969 год, арк. $5 ; 7$.

7. ДАХО, ф.1178, оп. 1, спр. 383 Сметы предприятий коммунального хозяйства на 1938 год. Сведения о благоустройстве города за 1936-1937 годы, арк.1.

8. ДАХО, ф.1178, оп.4, спр. 32 Планы развития жилищно-коммунального хозяйства на 1950-1955 годы, арк. 80.

9. ДАХО, ф.1178, оп.4, спр. 120 Архитектурно-планировочные задания по благоустройству города за 1960 год, арк. $3 ; 8 ; 11 ; 15 ; 17$.

10. ДАХО, ф. 1178, оп. 4 , спр. 36 Годовой отчет основной деятельности конторы благоустройства города за 1950 год, арк. 104.

11. ДАХО, ф. 1178 , оп.4, спр. 46 Годовой баланс основной деятельности со всеми приложениями по конторе благоустройства города за 1951 год, арк. 117; 120; 121.

12. ДАХО, ф.1178, оп. 4, спр. 39 План мероприятий по благоустройству города на 1951 год, арк. $2 ; 7$.

13. ДАХО, ф.1178, оп. 4, спр. 107 Архитектурно-планировочные задания по благоустройству города 1958 год, арк. $2 ; 34 ; 35 ; 36 ; 49 ; 50 ; 53 ; 66$.

14. ДАХО, ф.1178, оп. 4, спр. 113 Архитектурно-планировочные задания по благоустройству города 1959 год, арк. $3 ; 7 ; 9 ; 11 ; 32 ; 34 ; 49 ; 52$.

15. ДАХО, ф.1178, оп. 4, спр. 121 Годовой план по благоустройству города на 1960 год, арк. 77.

16. Хмельницький саджає Дерева Миру // Проскурів. - № 613, квітень. - 2016. - С. 8.

17. У Хмельницькому зявилася нова алея життя // Проскурів. - № 612, квітень. - 2016. - С.1. 
18. Сомова Л. В. Плоскирів, Проскурів, Хмельницький / Л. В. Сомова // Місто Хмельницький в контексті історії України : матеріали наук.-краєзнавч. конф. - Хмельницький, 2011. - С. 363- 369.

19. Мамаєва М. Д. Вулиці міста розповідають : нарис. / М. Д. Мамаєва. - Хмельницький : Поділля, 1991. $80 \mathrm{c}$.

20. Ярема С. Озеленення: проблеми і перспективи / С. Ярема // Радянське Поділля. - 21 січня. - 1977. - С. 3.

21. Карлов К. Квітнути нашому місту / К. Карлов // Радянське Поділля. - 4 червня. - 1969. - С. 3.

22. Іваненко К. Вулиця наша, будинки наші / К. Іваненко, П. Головчук // Радянське Поділля. - 17 липня. 1973. - C. 4.

23. Про екологію міста Хмельницького // Проскурів. - № 3-4, 10 січня. - 2003. - С. 4.

24. Карлащук І. Думи про зеленого друга. За культуру рідного міста / Іван Карлащук // Радянське Поділля. 8 квітня. - 1961. - С. 4.

25. Обласний центр стане ще гарнішим [Охорона природи в місті Хмельницькому] // Радянське Поділля. 1 квітня. - 1970. - С. 4.

26. Місто та його екологія // Радянське Поділля. - 4 липня. - 1984. - С.3.

27. Хмельницький отримує схему озеленення за 365 тисяч гривень [Електронний ресурс]. - Режим доступу : Kminfo. cinfoo. com/news - 7837. html.

28. Програма охорони довкілля міста Хмельницького на 2016-2020pp. [Електронний ресурс]. - Режим доступу : www. Khmelnytsky. com / index. ptp.

\section{Примітки:}

1. Провулок Карла Лібкнехта - вулиця Подільська;

2. Вулиця Тельмана - вулиця Вайсера;

3. Бульвар Джержинського - вулиця Свободи;

4. Вулиця Кирова - Володимирська;

5. Вулиця Леніна - вулиця Проскурівська;

6. Вулиця Марії Трембувецької - та сама;

7. Вулиця 25 жовтня - вулиця Проскурівська;

8. Провулок Некрасова - той самий;

9. Вулиця Центральна - вулиця Проскурівська;

10. Вулиця Куйбишева - вулиця Зарічанська;

11. Вулиця Індустріальна - вулиця Чорновола;

12. Вулиця Старобульварна - вулиця Гагаріна;

13. Вулиця Жданова - вулиця Шевченка;

14. Вулиця Котовського - вулиця Проскурівського Підпілля

15. Вулиця Дзержинського - вулиця Свободи

16. Провулок Червоноармійський - провулок Європейський;

17. Провулок Кіровський - провулок Володимирський

Ганаба Дмитрий. Озеленение города Хмельницкого во второй половине XX в. В статье рассматриваются особенности озеленения городской инфраструктуры Хмельницкого во второй половине ХХ в. Указано, что актуальность и важность данной проблемы обусловлена потребностями создания устойчивой урбоэкологической системы, улучшения санитарно-гигиенических условий проживания и комфортного эстетического отдыха людей в городе. На основе анализа документов отдела городского коммунального хозяйства проанализировано состояние озеленения города. Указано на масштабность комплекса мероприятий по озеленению, осуществлявшихся на основе партийных и государственных программ. Особенностью озеленения Хмельницкого, сохранившаяся до сих пор есть связь с государственными праздниками и юбилеями.

Положительным фактором в процессе озеленения было привлечение общественности к высадке большого количества деревьев и кустов и уходу за молодыми насаждениями. Практика использования усилий общественности в сохранении растений и увеличение их количества и ассортимента в парках, скверах и улицах города должны быть учтены в перспективных планах по озеленению. Характерным недостатком в процессе озеленения, что приобретает углубление и до сих пор, является бессистемность в подборе ассортимента растений, незначительное разнообразие их видового состава, отсутствие научного подхода в проектах озеленения города и т п. В процессе озеленения практически не учитывались климатические характеристики городской территории, санитарно-гигиенические условия и экологические особенности урбанизированной среды.

Ключевые слова: древесные насаждения, озеленение, урбоэкологическая система, комплекс мероприятий, методы, растения. 
Hanaba Dmytro. Greening of the City Khmelnitsky in the Second Half of the Twentieth Century. The article discusses the features of greening urban infrastructure of Khmelnytskyi in the second half of the twentieth century. It is noted that the relevance and importance of this problem stems from the needs of creating a sustainable urboekological system, improvement of sanitary and hygienic conditions and comfortable aesthetic rest of the people in the city. Based on the analysis of documents city municipal department analyzed greening the city . Specified the magnitude of a complex of actions on gardening, was carried out on the basis of party and government programmes. The feature of landscaping Khmelnitsky which survived and till nowadays is a connection with national holidays and anniversaries.

A positive factor in the process of landscaping was the involvement of the public in planting large number of trees and shrubs and care for young plantings. The practice of using the efforts of the public in plant conservation and increase the number and range of parks, squares and streets should be considered in future plans for landscaping. The characteristic deficiency in the process of gardening that becomes a deepening, and still is unsystematic in choosing the variety of plants, a small variety of their species composition, the lack of a scientific approach to the landscaping projects of the city. In the process of landscaping were hardly taken into account the climatic characteristics of the urban area, sanitary conditions and environmental features of the urban environment.

Key words: tree planting, landscaping, urboecological system, a set of measures, methods, plants.

Стаття надійшла до редколегії 14.09.2016 р.

Інна Зубцова

\section{Онтогенетична структура ценопопуляцій Polygonum Aviculare L. в умовах Кролевецько-Глухівського геоботанічного району}

У статті наведено онтогенетичну характеристику ценопопуляцій Polygonum aviculare L. на луках Кролевецько-Глухівського геоботанічного району. Розраховано індекс віковості за А. А. Урановим $(\Delta)$ та індекс ефективності за Л. В. Животовським $(\omega)$. Визначено належність кожної з досліджених ценопопуляцій до певної категорії, згідно з класифікацією Т. О. Работнова (інвазійні, нормальні, регресивні), Л. В. Животовського (молоді, перехідні, зріючі, зрілі, старіючі, старі). Побудовано та проаналізовано онтогенетичні спектри ценопопуляцій P. aviculare в аспекті їх належності до одного з типів: лівобічні, центровані, правобічні. Визначено частку рослин різних онтогенетичних станів у шести популяцій $P$. aviculare. На основі отриманих результатів зроблено висновки про онтогенетичну структуру ценопопуляцій $P$. aviculare в умовах досліджуваного району.

Ключові слова: Кролевецько-Глухівський геоботанічний район, Polygonum aviculare L., онтогенетичні спектри, онтогенетична структура, фітопопуляції.

Постановка наукової проблеми та ії значення. У наш час, незважаючи на неймовірні досягнення у сфері синтезу лікарських препаратів, використання лікарських рослин не лише не знижується, а навпаки - суттєво зростає [12]. Висока ефективність лікарських рослин визначається наявністю в органах рослин біологічно активних речовин, які, діючи на ті чи інші органи людини, викликають терапевтичний ефект. Перевагою лікарських рослин $є$ їхня мала токсичність і можливість довготривалого прийому без істотних побічних наслідків.

Однак заготівля лікарської сировини часто супроводжується цілеспрямованим вилученням зі складу фітоценозів особин, найцінніших за життєвістю, онтогенетичними показниками. Це суттєво зменшує здатність ценопопуляцій до сталого та довготривалого існування. Для запобігання таким явищам потрібне поглиблене вивчення стану ценопопуляцій лікарських видів рослин [13]. Один із таких ефективних методів - аналіз онтогенетичної структури ценопопуляцій. Біля його витоків стояли такі геоботаніки, як Т. О. Работнов [11] та О. О. Уранов [14; 15]. Також свій внесок у вивчення популяцій на основі популяційно-онтогенетичного підходу зробили О. В. Смирнова, Л. Б. Заугольнова [16; 17].

Зважаючи на зазначене вище, вивчення онтогенетичних характеристик ценопопуляцій дикорослих лікарських рослин уважаємо актуальною науковою проблемою. В Україні одним з осередків

(C) Зубичова I., 2016 